\title{
THE FORMATION AND DEVELOPMENT OF CONCEPTS ABOUT THE DESIGN SCHEME OF STRUCTURES
}

\author{
Anatolii V. Perelmuter \\ SCAD Soft, Ltd, Kiev, UKRAINE
}

\begin{abstract}
The history of the formation and development of design model concept of a structure accompanied structural mechanics at all stages have is analyzed in the paper. The main principles used at constructing design models are considered. New problems arisen in the process of computer-aided structural analysis also are specified in the distinctive paper.
\end{abstract}

Keywords: design scheme, structural mechanics, finite element method

\section{СТАНОВЛЕНИЕ И РАЗВИТИЕ ПОНЯТИЯ О РАСЧЕТНОЙ СХЕМЕ СООРУЖЕНИЯ}

\author{
А.В. Перельмутер \\ НПО «СКАД Софт», г. Киев, УКРАИНА
}

\begin{abstract}
Аннотация: Анализируется история становления и развития понятия о расчетной схеме сооружения, которое сопровождает строительную механику на всех этапах ее существования. Рассматриваются основные принципы, используемые при построении расчетной схемы. В настоящей статье также указывается на новые проблемы, возникающие в процессе компьютеризации расчетов.
\end{abstract}

Ключевые слова: расчетная схема, строительная механика, метод конечных элементов

The creation of design models of structures is simultaneously a task of experts in structural mechanics and of those in structures. Various approximations of the real physical service of a structure may be created only under their joint work.

\section{I.I. Goldenblat, V.L. Bazhenov}

A design model reflects a designer's idea of the real investigation object and peculiarities of its behavior. It is a simplified object model deprived of insignificant details and closely related to a set of some physical notions of laws, which control the investigation object behavior. Nowadays great experience exists in the design model development, and, preceding from this experience, in each specific case the following "type members" are used: such as shape idealization (a bar, plate, shell), regularities of material behavior (elastic, plastic, etc.), rule of these members coupling, etc. This designer's arsenal was developed in the course of the whole history of structural mechanics as science and continues perfecting in the present.

\section{BEGINNING OF THE PATH. ANALYSIS OF CERTAIN PROBLEMS}

An idea of a design model probably appeared simultaneously with science of strength in 1638, when the book by Galilei Disputes and Mathematical Proofs Concerning Two New Sciences was published, though the term design model appeared much later.

Just first attempts of design analysis of structure behavior, the attempts, which were aimed at the search of failure load, proceeded from certain hypotheses on location of dangerous section and 
force distribution in it. A set of these hypotheses could be called now a design model or design diagram.

Galilei thought rigid bodies to be inelastic and studied the problem on the bar strength, considering it in the state of failure (limit state in terms of the present). He attributed failure to two types of deformation - tension and bending.

a)

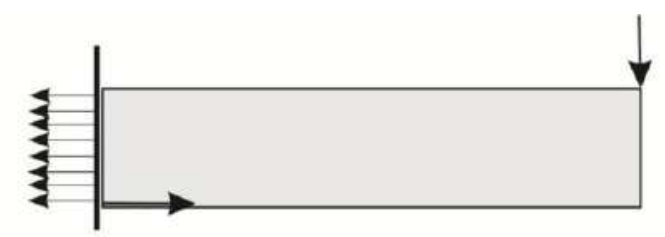

б)

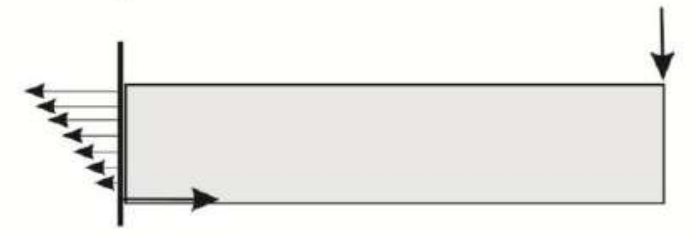

в)

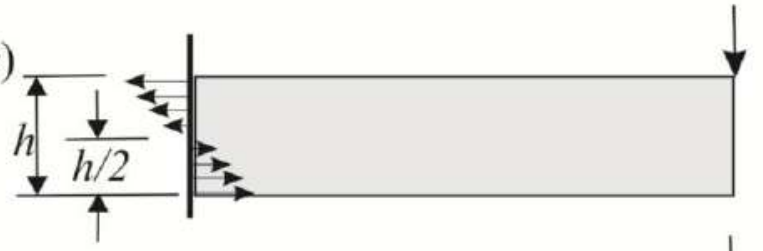

2)

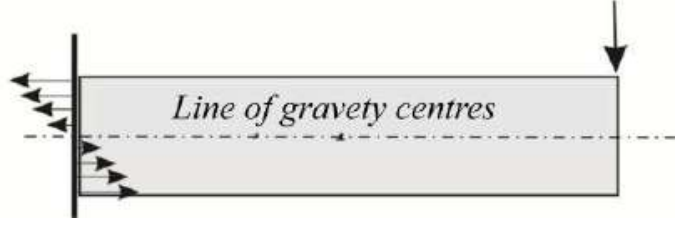

Figure 1. Bending resistance.

In the first case strength was taken as proportional to the cross-section area, Galilei bound the second case with the first one, supposing that the cantilever break occurs by crack opening displacement from above and rotation about the lower rib, the whole section being uniformly extended (Fig. 1,a). A question of the break place was not raised in the explicite form, Galilei probably thought it obvious.

Several laws of stress distribution throughout the section height were further offered: Mariotte [Mariotte, 1686) and Leibniz [Leibniz, 1684) considered the distribution as linear with coordinate origin at the section edge (Fig. 1,b), while Parent [Parent, 1713] used the same law, but distributed the coordinate origin in the centre of the section height (Fig. 1, c). And only Navier [Navier, 1826] placed the coordinate origin in the centre of gravity (Fig. 1, d). At last Persi, Navier's companion-in-arms at the school of bridges and roads, when developing Navier's approach, introduced an idea of the section inertia moment, which becomes and still remains a necessary attribute of the description of the schemes of bar structures.

The approach, which was based on the search for the break patterns and used a model in a form of a set of infinitely rigid blocks (the loss of link among them being connected to one or another extent with the break) prevailed in the problem of arch strain for a long period of time [Bernshtein, 1936]. An important point is that the shearing schemes appeared among possible break schemes (Fig. 2).
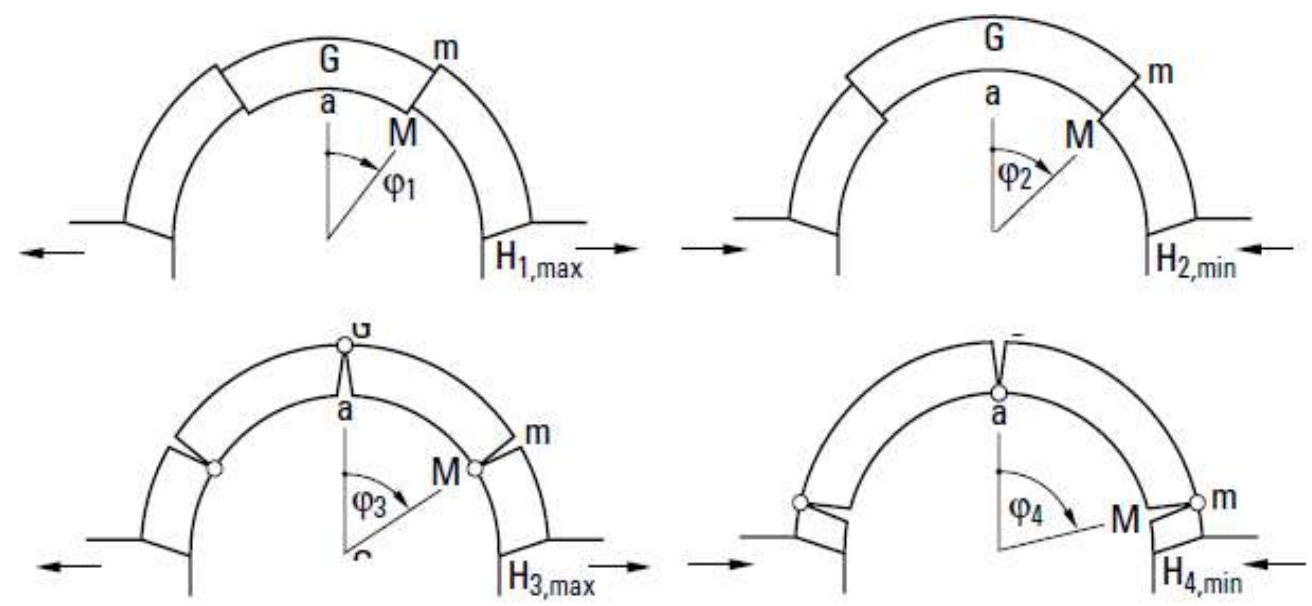

Figure 2. Coulomb's variants of arch destruction. 
The problem on the shape of flexible filament also belongs to the first period of formation of structural mechanics. It developed in two directions. The first one was connected with the problem formulated by Jacob Bernoulli: "to find what shape takes a rope freely hanged at two points", and this direction has played the important part in formation of mathematical analysis.

Another direction may be connected with the name of Varignon, whose major work [Varignon, 1725] was published after his death and dedicated to the theory of funicular polygon the design model, which is one of the principles of graphostatics.The problem on the funicular polygon attracted interest 100 years later in connection with the problem of design of suspended bridges, which chains were funicular polygons.

The discovery of Hooke's law in 1660 and the establishing of Navier's equations in 1821 are undoubtedly two important milestones in the further development of the theory initiated by Galilei. Hooke's law gave a necessary experimental substantiation of the theory.

In the period between deducing the Hooke's law and establishing general equations of elasticity theory obtained by Navier the interest of researchers was directed to solution and generalization of Galilei's problem, to allied problems which concerned vibrations of bars and plates. The first significant research in this field was made in 1705 by Jacob Bernoulli. It concerns the shape of an elastic curve of a bar and is based on the admission that the resistance of a bent bar depends on tension and compression of its longitudinal fibers.

When deriving the bar bending equation J. Bernoulli used the Hooke's law, and besides, two following hypotheses:

- the sections, plane and perpendicular to the prism ribs before its bending, remain after the bending plane and normal to these ribs and fibers or longitudinal members that become curvilinear;

- the fibers, some of them being extended others - shortened, resist independently the bending, as if they were small isolated prisms, taking no effect on one another.

The same propositions were further taken by Euler in his research, which concerned the problems of elastic line and vibrations of thin bars. The Euler-Bernoulli design model of a bar presented an elastic bar in a form of a linear set of particles resisting the bending.

The successful development of the theory of thin bars, based on special hypotheses, led to a conclusion that the theory of plates and shells may be constructed in the same way. Euler was the first, who was concerned with this problem. He offered to consider a bell as a set of thin rings, each of them behaving as a curved bar. This work was followed by the research of Jacob Bernoulli (junior). He considered a shell as a double layer of curved bars, the bars of one system intersecting with the bars of the other system at the right angle [Bernoulli, 1789). Reducing a shell to a plane plate, he obtained an equation, which, as we know it today, was incorrect (he excepted twisting for the bar).

The attempt of Jacob Bernoulli was, probably, a purpose to obtain theoretical substantiation of experimental results by Chladni [Chladni, 1802], as to the figures of nodal lines observed under plate vibrations.

These results remained unexplained, when in 1809 the French Institute offered the problem on the tones of plate vibrations as a bonus theme of scientific work. After some attempts there appeared a work by Sophie Germain awarded in 1815 and published only six years later [Germain, 1821].

But a distinct design model of a bending plate was proposed only in 1850 by Kirchhoff [Kirchhoff, 1850], who based his theory of plates on the following two hypotheses, generally recognized nowadays:

- each straight line, which was first perpendicular to the midplane of a plate, remains under bending a straight line normal to the middle surface of a bent plane;

- elements of the plate midplane are not elongated at small plate deflections under transversal load. 
These admissions are close by content to hypothesis of plane sections taken today in the elementary theory of bar bending.

\section{ELASTIC BAR SYSTEMS}

Before the 30 's of the $19^{\text {th }}$ century structural mechanics had in possession the design models of bars, arches and plates - the base elements composing real structures. All these design models were realized separately, while they interact in numerous cases, being separate fragments of a more complex structure. If in the $18^{\text {th }}$ century the design and technical development of civil engineering was concentrated on stone arches, than in the $19^{\text {th }}$ century the interest of engineers changed and they were oriented to analysis of skeleton constructions. In connection with a rapid development of railway engineering the transition from elementary carrying systems to composed constructive designs was much more prompt than in cast-in-place constructions (such as masonry and concrete), under these conditions geometrical and physical properties of such structures became a logic abstraction of the design model in a form of a truss.

Such a design model was used to construct bridges with various structural systems, proposed by James Warren, Stephen Harriman Long, William Howe and other inventors [Perelmuter, 2015].

The considerable number of wooden bridges in North America was described by Carl Culmann, indicating those with the signs of damage and failure, in spite of the generous use of materials [Culmann, 1851]. Culmann indicated different structural systems in those bridges and noticed that they could better perform their function on condition of correct design.

He created a theory of braced structure, based on the following admissions:

- a system of filling with bars between the top and bottom chords should be made in such way that all the bars formed triangles;
- the bars should have a possibility to turn in joints without restriction

Using the equilibrium conditions Culmann could calculate forces in the elements of any statically determined girder structure of the above type.

The work by Schwedler [Schwedler, 1851] appeared almost simultaneously, the author indicated (see Fig. 3):

"If a structure as a whole is considered as rigid, small resistances caused by elastic bending at the points $a, d, c$, etc. are insignificant compared with resistance of braces, or, in other words, it may be taken that separate components of the truss can turn at the points $a, d, c$, etc."

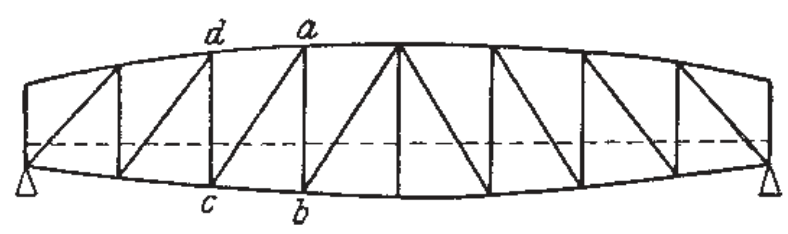

Figure 3. Hinged model of Schwedler frame.

Schwedler has first performed the process of abstraction, which is typical of the structural theory: from the physical carrying structure (real through system, e.g. wooden truss) through the abstract carrying system (model of a through structure or girder bar system according to Culmann) to design model (of a hinged truss), described with the help of physico-geometrical properties.

The invention of design model in a form of hinged truss has become a key concept for development of the structural theory in the second half of the $19^{\text {th }}$ century. It is important that independent analysis of topologic structure might be made for this model. Such analysis was intensively developed in the works devoted to revealing kinematic properties of truss structures and then of the bar structures of any other kind.

Another important achievement, which originated from the design model of the truss, was the development of the conception of a node - a hinge joining the truss bars. Then the node hinge was considered as a material point, the equilibrium equation being formulated for it, 
and in this quality the node became an integral part of design model of the bar (and not only) systems. The design model of a truss was rather evident, and the truss work proved very positive. Many engineers tried to construct the truss model. Schwedler developed hinged nodes for the bridge over the Brache river (now the Brda river) near Czersk built by his project in 1861 (Fig. 4). But nine years later the other bridge over the Brache river was constructed near Bromberg (today Bydgoczsz), and now by Schwedler's project using riveted joints.

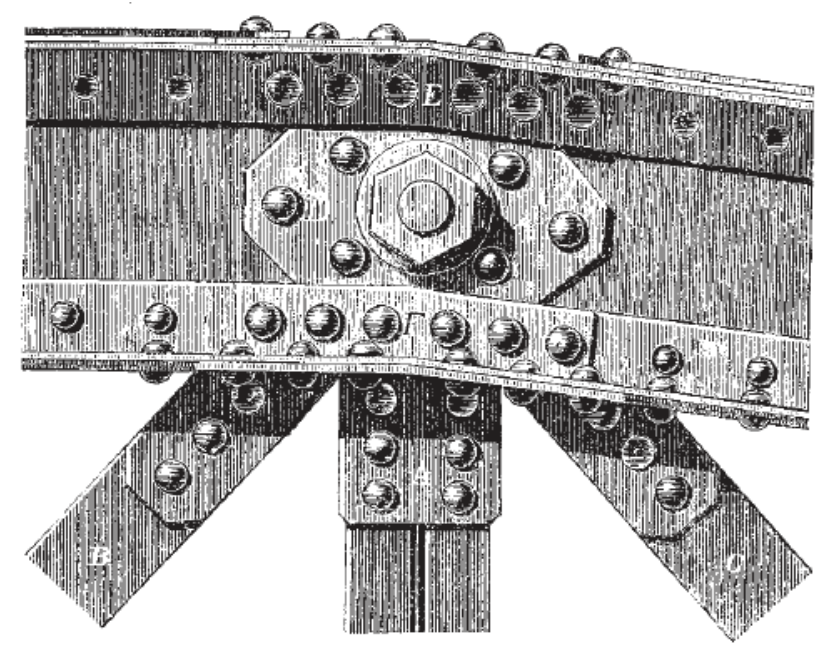

Figure 4. Bridge truss nodes.

Emil Winkler realized that the hinged model of the truss did not correspond to real work of metal trusses with riveted joint [Winkler, 1872]. Some bending moments appear due to the node rigidity in the truss bars, and as a result - additional stresses. The problem of their determining that first of all attracted attention of Manderla [Manderla, 1880], resulted in the appearance of the method of displacements.

Design models of skeleton structures, where most nodal joints are rigid, began quickly extending in connection with construction of reinforced concrete frames. And design model of a truss with ideal hinges proved to be a certain approximation to reality.

E.O. Paton estimated the degree of relative increment of stresses that appear at the expense of node rigidity [Patton, 1901], and as his studies have shown, the more precise is the "truss ap- proximation" the more is the flexibility of the truss bar elements. In essence, there arised an important question, which soon arised in other situations: the question on usability limits of one or another design model, of the necessity of its specification or cardinal change, when its parameters are outside a certain limit.

For example, S.P. Timoshenko proposed a model of a bending beam, which difference from the Euler-Bernoulli model is that under deformation the cross-sections remain plane but not perpendicular to deformable midline of the bar, and inertial components connected with a turn of cross-sections are accounted in dynamics [Timoshenko, 1916]. E. Reissner proposed an analogous perfection of the Kirchhoff model for plates [Reissner, 1945]. In both cases the point was in the necessity of introducing some specifications, when shearing deformations begin playing a considerable part.

The transition from analysis of truss models to investigation of frame systems became a largescale one at the end of the $19^{\text {th }}$ century and especially in the first half of the $20^{\text {th }}$ century. That was caused by the intensive use of cast-in-place reinforced concrete constructions in civil engineering.

Formulation of the problem on general rules of development of design models belongs to the first quarter of the $20^{\text {th }}$ century, and here we should note the work of N. Gersevanov [Gersevanov, 1923], who has first formulated that:

- the design model is constructed proceeding from the expected form of failure and deformation based on the experience of building practices;

- the design model uses only hypotheses concerning the structure properties and actual loads, which allow developing the efficient methods of calculation.

The design model substantiation problem itself, besides the use of the results of experimental studies, developed in the following direction. Researchers proposed the ways to transform the design model of a more general form, e.g. a model of three-dimensional continuum of the problem of elasticity theory, to one or another 
model of the structural unit of a certain type. Such an approach was especially often used in development of the theory of plates and shells. The first attempt of deriving equations of the theory of shells from the equations of elasticity theory was made by G. Aron [Aron, 1874]. Then this trend was developed in the works by A. Love [Love, 1888], A. Basset [Basset, 1892], H. Lamb [Lamb, 1890], A.I. Lurie [Lurie, 1947], et al.

After deriving the resolving equations of the shell theory and developing the corresponding design models researchers began developing various non-classical variants of the theory. Here one should recall the theory of shells of Timishenko-Reissner type that allow for longitudinal shear deformations. Besides, the theory of the ribbed and multilayered shells may be referred to non-classical ones.

First works in this field for the plates reinforced by ribs were made by I.G. Bubnov [Bubnov, 1904]. The theory of ribbed shells of a general form was presented in the works by A.I. Lurie [Lurie, 1947] and V.Z. Vlasov [Vlasov, 1949]. A.I. Lurie considered ribs as the KirchhoffClebsch bars, while V.Z. Vlasov considered them as thin-walled bars.

Multilayered shells were investigated from different viewpoints in a lot of works mainly in two basic directions. The first one includes theories based on design models, where kinematic hypotheses were taken for the whole set of layers. The first-stage researches have demonstrated nonperceptibility of this approach, if properties of the layers are essentially different; that is why the works of another direction were developed in recent years; a complicated design model, where kinematic hypotheses are taken separately for each layer, was used in these works.

\section{STRUCTURAL ANALYSIS}

A detailed analysis of separate problems and simple objects led to development of such a notion as a material point, absolutely solid body, elastic bar, plate, etc. The properties were stud- ied for them, which are used, when a more complex model of the problem required is constructed using such parts as of a certain "constructor". And a problem of analysis of the composed design model of such kind appeared in natural way. Most researches were devoted to design models of trusses; they attracted by their "homogeneity" and distinct division of topologic (structure, fixing) and metric (node coordinates, section sizes) data.

As to the complete system of determining equations we should say that Alfred Clebsch has shown in his work [Clebsch, 1862] that a set of equilibrium equations and those of deformation compatibility for an arbitrary truss has the solution [Clebsch, 1883]. But the problem of solution possibility was, first of all, considered from the viewpoint of equilibrium equations issuing from the composed design model - equations of analysis of its statical determinability and invariability. Even in 1837 A.F. Möbius proved the theorem that to obtain a rigid invariable structure in a truss with $n$ hinges it is necessary to have no less than $2 n-3$ bars in a plane system and no less than $3 n-6$ bars in the case of a spatial system [Möbius 1837]. In so doing he has probably first indicated a possibility of existence of exceptional configurations, when one observes infinitesimal mobility without bar deformation (a case of instant variability in the current terms)

When studying these cases Möbius has found that therewith a determinant of the set of equilibrium equations becomes zero. The connection between the variability criterion and degeneracy of the system of resolving equations became after a while the basis for computer analysis of kinematic properties of design system of any (not only truss) type. The results obtained by A.F. Möbius, which then remained unknown, were found again by P.L. Chebyshev [Chebyshev, 1870] and Otto Mohr [Mohr, 1874] and only then entered in the design practice.

Mass enthusiasm as to the method of forces, characteristic of the end of the $19^{\text {th }}$ and first half of the $20^{\text {th }}$ century, resulted in the appearance of various procedures of construction of the basic system of this method and in the problems of 
revealing the redundant constraints in statically undeterminable design models. Relations between the properties of static determinability, invariability and ability to realize the pre-stress were studied in detail for the bar systems. Researchers indicated methods for determining statical-kinematic properties based on reducing the system to a certain number of hard discs, bound by bars-restraints. They also introduced the notions of simple and multiple hinges and other idealized elements of the design model.

Noticeable changes in the concepts of design model are connected with the transition to displacement method analysis. In the displacement method the system elements are considered to be connected with the nodes of the design model, they are not connected directly with one another. The above peculiarity of the design model construction was often disregarded by engineers educated on the ideas of design model in the style of the force method, it is not always seen, when using the methods of design model representation that is traditional for the force method. Thus, the design system presented in Fig. 5, $a$ in traditional form, inherent in the force method, can suggest the point-to-point connection of elements with one another, while a more detailed representation in Fig. 5, $b$ allows avoiding such conclusion. Note also that in the detailed presentation one can also see other peculiarities of the design model implementation, in particular, a possibility to meet similar kinematic conditions with using various sets of constraints imposed on the nodes, and conditions of elements connection with the nodes.

Neglect of the above difference is not always safe. For example, from the viewpoint of kinematic properties of the problem two variants of the design model, presented in Fig. 6, have equal rights (a beam is fastened in its left end and hinged in the right one).

But from the viewpoint of giving forces these variants differ - in the scheme of Fig. 6,b the moment is transferred to the bar, and node 2 in this scheme turns, and in the scheme of Fig. 6,a the moment is not transferred, and node 2 of this scheme has zero turning angle. a)

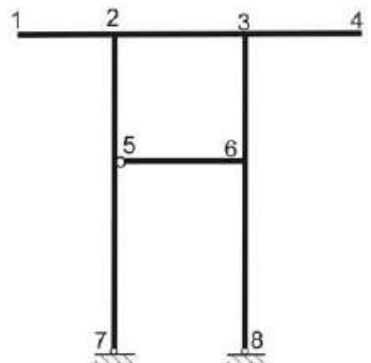

b)

Figure 5. Presentation of design model: $a$-traditional; $b$-detailed.

a)

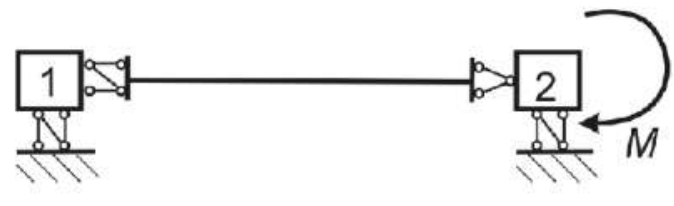

b)

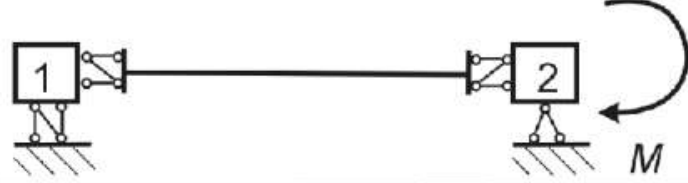

Figure 6. Two variants of presentation of one design model.

For a bending moment to appear in a bar in the scheme on Fig. 6,a, it should not be considered as nodal, but applied to the bar in the section near a node.

The above division of topologic and metric properties of the design model gave impetus to the works connected with the use of graph theory to analyze properties of bar systems. Such was the approach in the pioneer publications [Fenves \& Branin, 1963], [Perelmuter, 1965], while in the work by Di Mattio [Di Mattio, 1963] the degree of static indeterminability is studied just as topologic property of the design system. Later on there appeared works, where topologic connectedness of design model was compared with the structure of distribution of nonzero elements of rigidity matrix of the system that is analyzed, and a possibility of optimal enumeration of unknowns [Akyjz \& Utku, 1968], [Clempert, 1973]. Researchers proposed some artificial techniques aimed at the improvement of the above structure even at the expense of increasing the rigidity matrix order [Perelmuter, Slivker, 1976]. 
Practical interest to the analysis of suspended and rope systems, characteristic of the works of the second half of the $20^{\text {th }}$ century, resulted in a detailed study of topologic and metric properties of degenerated (instantly variable and instantly rigid) systems. There appeared a number of fundamental works [Kuznetsov, 1960], a lot of researches were initiated by introduction of the systems of "tensegrity" type by Buckminster Fuller [Fuller, 1961]. He used this term to indicate the frame structures, involving continuous chains of members, which work in tension, and inserted members, which work in compression.

Study of properties of instantly rigid systems and systems of "tensegrity" type preferred to come back to general principles of analysis of static-kinematic properties of the composite design models [Shulkin, 1977], [Calladine, 1978], [Connelly, 1980]. The systems with unilateral constraints, possible combinations of static and kinematic properties being established for them [Perelmuter, 1968], were also considered.
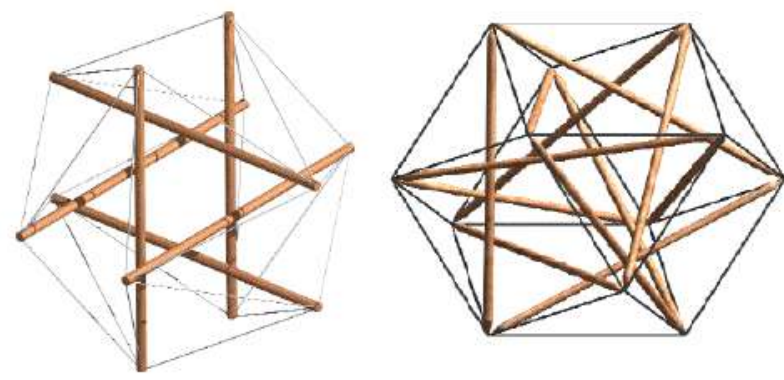

Figure 7. Examples of tensegrity structures.

\section{DESIGN MODELS OF THE FINITE EL- EMENT METHOD}

The appearance and development of the finite element method (FEM) has told essentially on the problem of choice and substantiation of the design model. Even a description of geometrical pattern of the structure became a choice of designer, as it occurs in the problems, where a curved shell surface is modeled by a multiface set of plane finite elements. However, such a problem also appeared before, when they used an approximate description of curved bars by a certain polygon.

A possibility to present a design model as a set of finite elements, their quantity in configurations being limited by nothing but the library of finite elements at designer's disposal, raised in a new fashion the question on the number of basic unknowns, degree of kinematic and static indeterminability and other still inviolable characteristics of the design model of the building. The number of unknown displacements (the degree of kinematic indeterminability) stopped being the problem feature and became a subject of designer's self-will.

Some "standard" approaches to composing the finite element design models were developed for most types of structural systems. For example, at the first stage of using FEM a design model of a thin-walled fuselage structures and aircraft wings became popular; it was composed of shearing panels and a frame of bars, supporting them at the edges, able to take up only longitudinal forces.

In such wing model (Fig. 8) the bars simulate the work of longitudinal members of the wing structure under load; these members are subjected to compression and extension under the wing bending. Plates simulate the work of walls, which prevent shearing, as well as the external and internal wing covering.

This model was propagandized by G. Argyris [Argyris \& Kelsey, 1954], and though it appeared long before FEM [Ebner \& Köller, 1937], [Umansky, 1950], its implementation proved acceptable only in the framework of FME, though it existed there just for several years. Potentialities of computation complexes, which were quickly perfected, permitted even in the 70 's of the $20^{\text {th }}$ century specifying the design model and taking account of bending strains of the supporting frame.

There originated new approaches to design model development for the plates and shells with ribs. There also appeared competing propositions as well as the problem of their verification. 


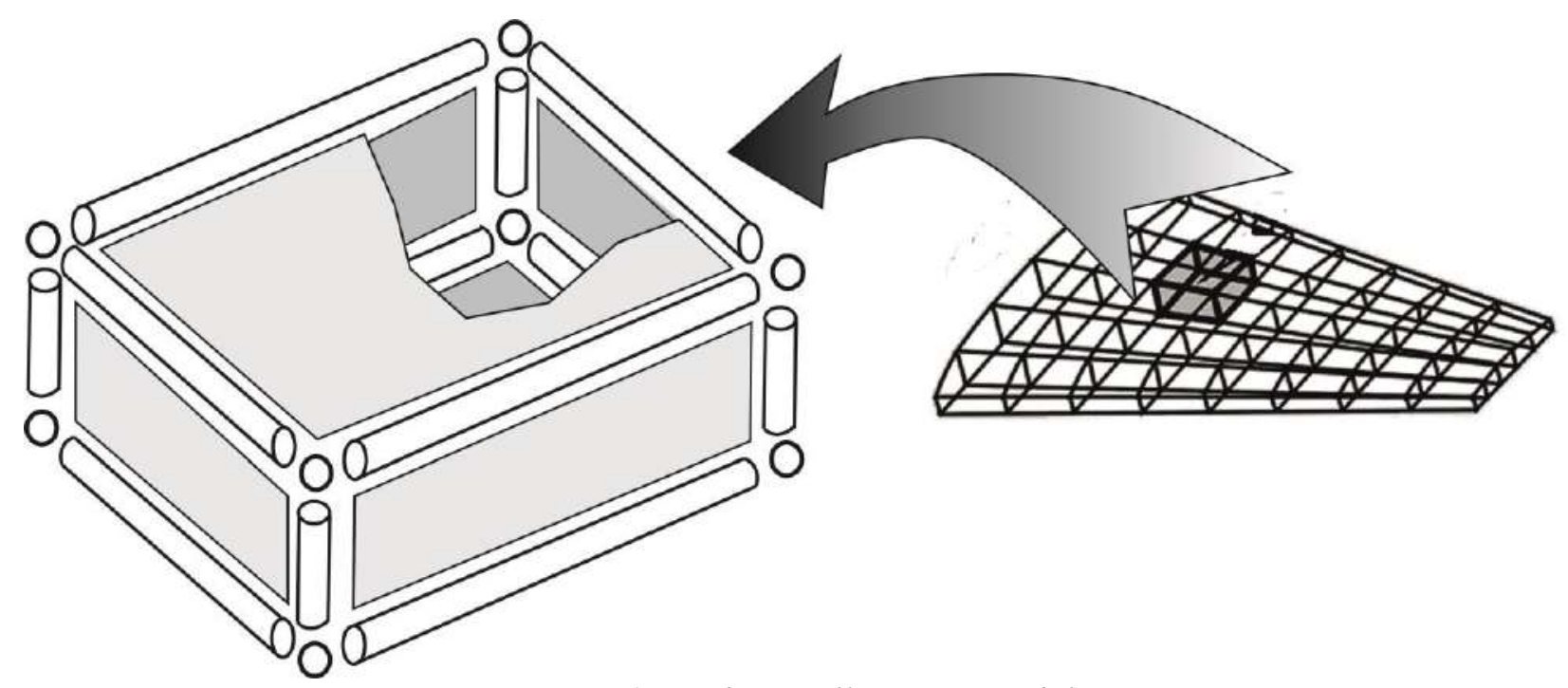

Figure 8. A thin-wall system model.

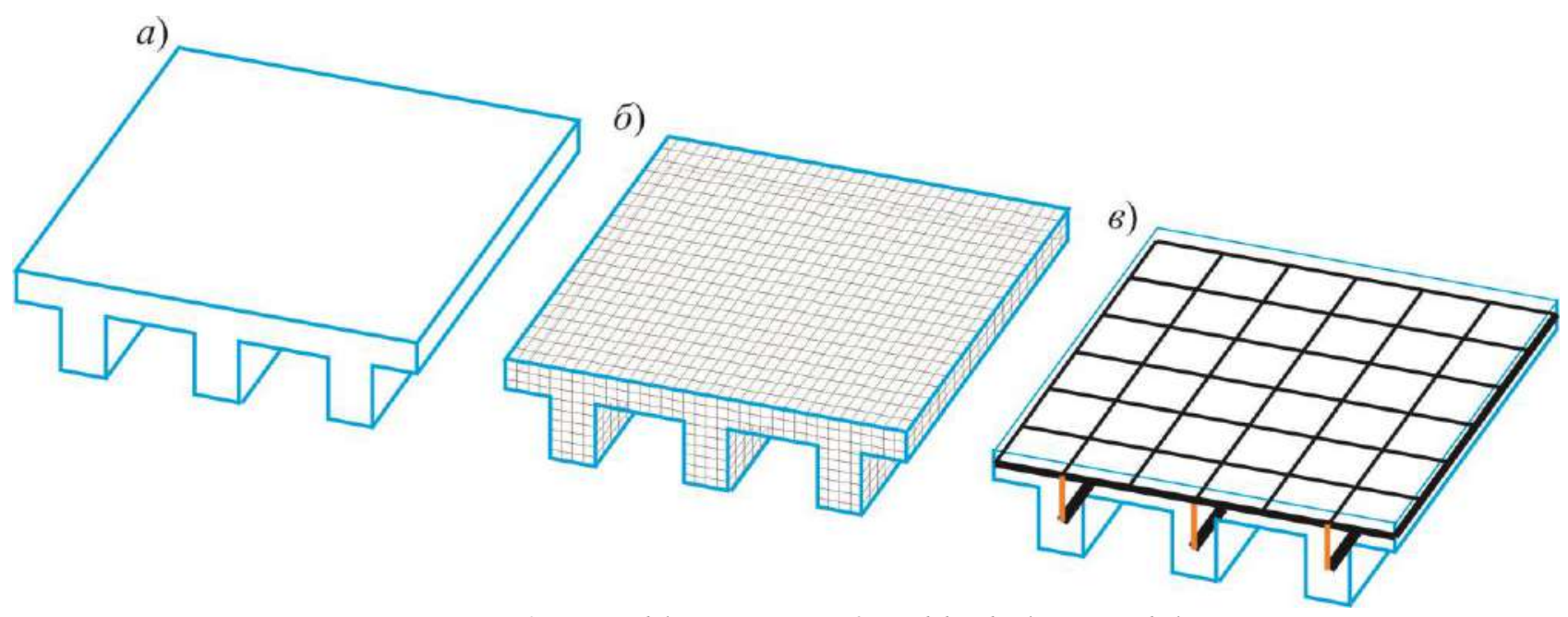

Figure 9. Possible variants of a ribbed plate modeling.

The corresponding example of the variant of a design model composed of solid elements (Fig. $9, \mathrm{~b}$ ) and the variant of modeling using plate and bar elements connected through infinitely rigid inserts (Fig. 9, c) are presented in Fig. 9.

In industrial and civil buildings, where, e.g. the through columns are used, designers often abandon presentation of such a column as a solid rigid bar, but use a more detailed description of the structure. And above all, they practically gave up plane design models and resolve all problems with the use of three-dimensional models. The main trend of development is now the use of more outsize design models; the number of unknowns of the order of hundreds of thousands became ordinary in the design practice; in so doing such an extensive detailing is not always necessary but connected with formal construction of the design model by the data of graphical program used for making drawings.

A possibility of modeling structures of arbitrary nature, including those which separate parts are presented by bars, others - by plates or shells, the third - by three-dimensional bodies, raised questions as to connection of finite elements of different type and arising problems, caused by the difference of nodal degrees of freedom in different type elements. A necessity of using special techniques (Fig. 10), for example, such as the introduction of the bar element into the rigid disc body, is indicated [Perelmuter, Slivker, 2001]. 
a)

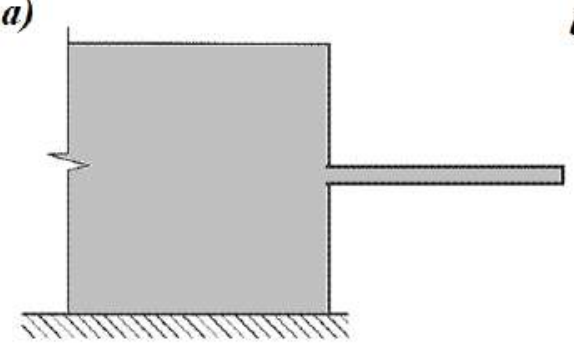

b)

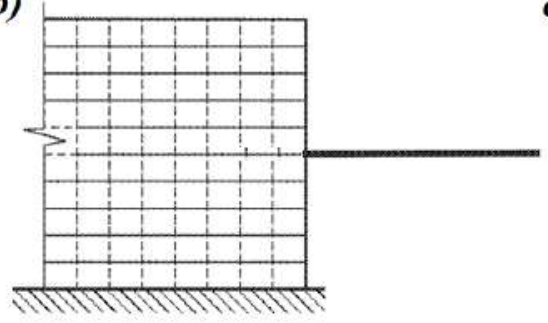

c)

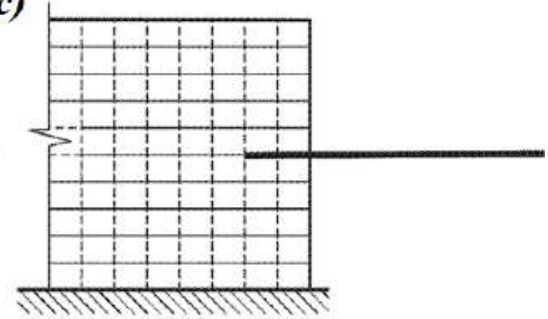

Figure 10. Modeling of interconnection of a bar and disc: $a$-task; $b$-variant, which does not provide a restraint; $c$-recommended decision.

But it should be allowed for that the above result may be lost because of difficulties in analysis and comprehension of excessive information. And this so-called revision often leads to shading the basic features of the structure service, and its simplified variant is considered for their analysis in parallel with a detailed design model. In so doing there sometimes arises a nontrivial problem of results comparison; it is especially difficult, when there is no exact fit between the elements of compared design models [Perelmuter, Slivker, 2001].

And finally note that the analysis of design models of the finite element method is closely connected with the problem of method convergence. Mathematical proofs of the corresponding facts (for example, a demand of compatibility of the fields of displacements) require their interpretation in terms of design models, which are successively "concentrated". In particular, in the case of incompatible elements it should be remembered that the solving of design problem is equivalent to minimization of full potential energy of the system (Lagrange functional), and approximation of the displacement field by a certain finite set of preset functions narrows a possibility of arbitrary deformation, that is it may be treated as the imposing of some constraints. If elements are incompatible, some displacements are possible at their boundaries; these displacements do not exist in the continual design model (for example, mutual rotation angles of plates), and correspond to the absence of some constraints.

When the number of finite elements increases and their sizes decrease, the total number of the structure degrees of freedom grows, and thus, the effect of the imposed nodal constraints is reduced. This process, certain conditions being fulfilled, provides the method convergence for compatible finite elements. On the other hand, the same process leads to the decrease of mutual displacements at interelement boundaries in incompatible elements that may be treated as a certain locking of the preliminarily left constraints. Thus the convergence of incompatible elements can take place only when positive tendencies of overcoming the imposed constraints prevail over this negative tendency of imposing the constraints at interelement boundaries.

Other approximations are sometimes realized simultaneously with approximation of the displacement field; those are connected with a necessity of using a finite-element model that is the substitution of the structure geometry by that similar to it. In the system geometry approximation, both the geometry and boundary conditions may change, since the latter belong now to the boundaries with other configuration. Here one can run across the reefs, since the passage to the limit of the outline form is not necessarily accompanied by passage to the limit of kinematic properties. That is evidenced by well-known Sapondzhyan paradox for a freely supported polygonal plate [Panovko, 1985].

At the outset of FEM use they discussed a socalled problem of "small length" of the bar finite element, when a stress was made on the fact that a bar was defined (in courses of material resistance or structural mechanics) as the object, which one size (length) exceeded considerably 
other ones that defined cross-section dimensions. But in the design model in use the bar as the design model element may be found to be very short. There seemingly appears a violence of agreements concerning a bar definition. In fact, there is no violation, since the admission on a sufficient length of the bar was only required to substantiate the type of the corresponding differential equation. As to the method of its solution, when a bar is divided into rather small parts (read interval of integration), this has no effect on the equation form.

\section{SOME NEW TENDENCIES}

In recent decades there appeared a branch of structural mechanics based on probabilistic analysis, which started its intensive development. The approaches to the design system itself and to development of the corresponding design model have undergone considerable changes.

The whole identity of parameters of all similar structure elements is foreseen in a determined variant. It is considered that all the headers of a three-dimensional framework have equal spans, all the columns of these headers - similar sections, etc. In so doing all such type elements are reduced to one representative, and sometimes to its one section. Such an approach is acceptable under the approach to design contained in the design norms. The approach is based on the half-probabilistic method of limiting states. Then all the probabilistic characteristics are formulated and estimated beyond the design model, and a design contains only some guaranteed the worst statistical estimates of means, standards, quantiles, etc., which are really the same for all identical elements, since one of definitions of their "identity" is the identity of the distribution law.

The transition to really probabilistic design was connected with the fact that one has not to operate on distribution parameters of random values but on distributions themselves, when random parameters operate not outside but inside the design model. And in such a model each of "identical" substructures should be defined in a form of a set of mutually independent (or correlated) random values (probably functions) with the same distribution laws [Bolotin, 1971]. In such formulation one cannot imagine a design model, e.g. of a plane problem, which provides identity (or rigid correlation with correlation coefficient equal to one) of all plane subsystems distributed in parallel.

The following should be noted: a further detailing of the models, when passing to analysis of multielement structures (a building as a whole), requires the involvement of the great number of parameters, used for the model description. If these parameters are random values, which probabilistic properties are statistically justified, the degree of design model indeterminacy as a whole increases with the number of such parameters. Thus, if a certain result of analysis is in linear relationship with $N$ independent random parameters (e.g. external loads in the system nodes), the standard of this result is proportional to that of the input data (here loads) with a multiplier of $(N)^{1 / 2}$ order. It is simple to estimate what is the probability of the results of analysis at very high $N$ values.

There are more detailed propositions as to determining the effect of output data accuracy on the results of analysis (see, for example, [Podolsky, 1984]. They evidence that the information on the input parameters being insufficient, it is expedient to use simple design models. Such a peculiarity of design modeling is connected with the fact that the loss of information because of incompleteness of output data can exceed information accumulation at the expense of refinement of the design model.

The foregoing should be never considered as a panegyric to "good old days", when everything was solved using the formula $q L^{2} / 8$ and counted using a slide rule. The thoughtless complication of design models would be substituted by new culture of their use that includes also the estimation of possible uncertainty of solution. Now, having the modern means for analysis of complex and supercomplex systems, we study them 
in formulation of the problem, which rather corresponds to the $19^{\text {th }}$ than to the $21^{\text {st }}$ century.

At last, it should be mentioned that the above problem of output data influence on the design model form is inherent not only in the probabilistic problems. The choice and justification of the design model cannot be separated from the level of information as to the structure, which is designed as well as from the method of solving the mathematical problem, formed as a result of using the chosen design model.

And what is more, a lot of mathematical operations used, when solving a problem, often have a mechanical interpretation, which use helps understand the features of calculation process. As an example, we can refer to the interpretation of Gaussian algorithm for solving a canonical system of linear algebraic equations, as to the sequence of imposing (force method) or taking off (displacement method) constraints [Gantmacher, 1967]. Such illustration favors a better understanding of the problem.

\section{DESIGN MODEL JUSTIFICATION AS A SCIENTIFIC PROBLEM}

The justification of using a certain theoretical model is usually based on the following consideration. It is assumed that the result observed in a series of consistent experiments is always close to that predicted by theory. Hence, it can be concluded that the design model is applicable to the conditions similar to the experimental ones.

However, in order to decipher the concepts of "consistent experiments" and "the result is close to", and to assess the degree of similarity between the conditions of the problem and those of the experiments we have to use the theory which actually has to be justified by the experiment. For example, in order to make sure that there is no systematic error in the experimental data, it is necessary to compare the parameters of the experimental sample with the parameters of the model, and the justifying decision has to be made concerning the meaning and the num- ber of these parameters. There are two ways to break this vicious circle:

- to ignore these logical contradictions (the conventional, so-called, "engineering" approach);

- to make an attempt towards an axiomatic theory [Truesdell, 1975].

The latter approach [Truesdell, 1975] makes the theory of structures a logically coherent science (mathematics in a sense), but it poses untypical requirements to a practicing engineer. Namely, he has to think like a mathematician, referring to axioms in obscure cases and repeating the entire chain of reasoning that led him to the considered case.

Therefore, the first approach is commonly used in practice. Its applicability is formulated as follows [Kosmodemyansky, 1969]: “...when designing and building new structures (bridges, dams, airplanes, missiles, buildings) on the basis of tremendous experience, experts are so confident in the validity of the laws of mechanics that all the conclusions derived from the calculations are considered to be absolutely true. Any discrepancies between theory and practice are explained after a subsequent rigorous and thorough analysis either by inaccuracy of the initial data or by arithmetic errors".

Starting with the first quarter of the 20th century, the problem of justifying a design model began to be considered as a general scientific methodological problem, the authors of the corresponding papers put forward various rules for creating design models. For example, three principles for creating design models of structures are put forward [Gersevanov, 1923]:

- calculation methods should be based on the failure and deformation modes confirmed by the construction practice experience;

- the design hypothesis should subject the model to harder conditions than those the actual structure is subjected to;

- the set of design hypotheses should provide cost-effectiveness of the structure in addition to its strength and stability.

According to the authors [Goldenblat et al., 1979] these principles, however, are not com- 
plete, and they should be supplemented as follows:

- it is reasonable to have a system of approximating models of the structural behavior with their respective limits of applicability rather than a single model (for example, one model can be used to describe the elastic behavior of a structure and the other to describe the elastic-plastic stage);

- a model approximating the structural behavior should not only correctly and fully reflect the behavior of the real structure, but it should also be simple enough, so that the calculation does not become excessively cumbersome.

General modeling issues were developed and refined in the following works: [Buslenko, 1968], [Dickson, 1969], [Kartvelishvili and Galaktionov, 1976], [Perelmuter and Slivker, 2001], [Perelmuter and Kabantsev, 2015]. J. Dickson describes the process of creating design models (Fig. 11) and indicates that "a model is an idealized approximation to the real situation. Creating a good model involves making assumptions that take into account relative importance of various elements of the problem".

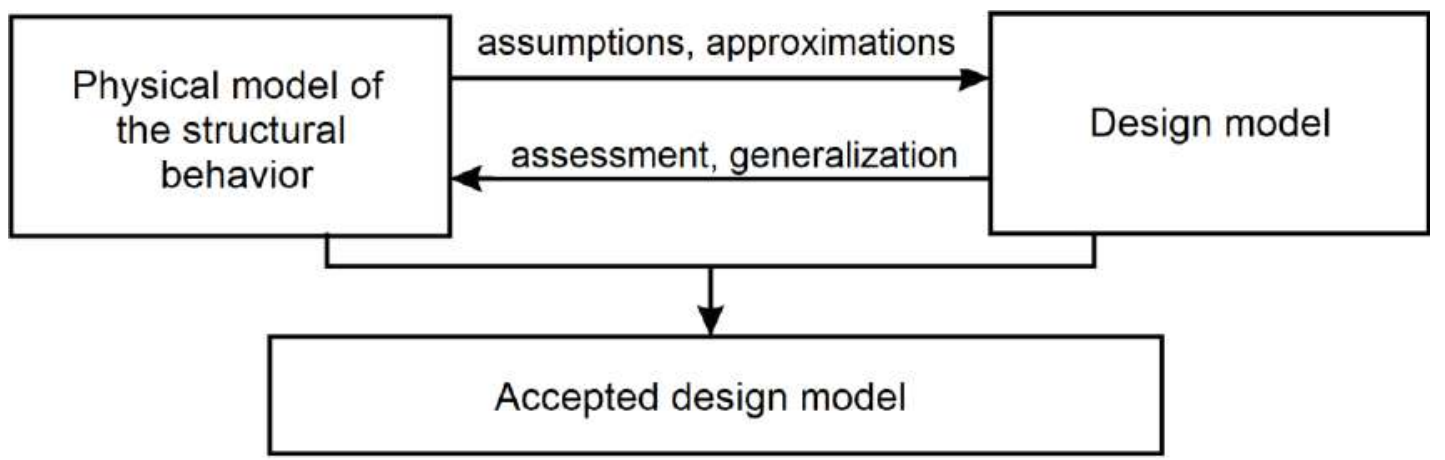

Figure 11. Logic flowchart for creating a design model.

A special role belongs to general models of typical structural elements (a bar, a plate, a shell etc.), which are used to create full design models of structures or parts of design models of other more complex structures. Such models should be studied as rigorously as possible and serve as a basis for further consideration of other design models. After such investigation, having a complete knowledge about these models makes their use quite attractive to an engineer, who can then anticipate the result of the analysis (or at least its qualitative features).

The transition from a structure to its design model made up of basic models is usually performed intuitively, and the geometric considerations ("similar" shape) are the first motive behind this transition. Though, there is room enough for a maneuver even here. The design process often involves such operations as the replacement of a lattice structure with a continuous one which has a shape only vaguely resembling that of the original structure, or "smearing" the ribs and other structural parts. There are opposite examples as well, when a continuous body is replaced with its bar analogue. Some knowledge about the peculiarities of the behavior of the selected basic models is used here in addition to their geometric shapes. For instance, if a plane section of the design model is described by purely flexural plate elements, we should keep in mind that the membrane components of the stress field cannot be determined in this case. If these components can be significant (e.g., they can cause buckling), it is more reasonable to use shell elements.

The second motive, which also plays a fundamental role in the transition to a design model, is a choice of one of the standardized idealizations of material properties (elastic, plastic, loose, etc.). These properties are also represented by previously studied basic models, and they would not be worth mentioning, if not for the following consideration: their choice requires an experimental justification even more than that 
of the geometric shape, but this stage is usually omitted.

The designer usually operates with the available data about the physical models of the material behavior obtained from experiments performed on other structural elements and samples. At best, such actions are justified by the fact that the results of these studies can be used in the created design model based on certain ideas about the possible nature of deformations and about the expected stress level caused by the loads of a certain level. The main role however is usually played by the tradition and the actual computational capabilities of the designer.

The use of computers has significantly expanded these capabilities, but has not made them limitless, although the finite element method implemented in the structural analysis software often creates the illusion that it is now possible to solve any problem. Quite late was it realized that the capabilities depend on the result representation methods, since the limitations of the human ability to analyze and perceive large volumes of information play an important role here.

Unfortunately, there is not system of clear integral characteristics that would alone enable to understand the structural behavior in structural mechanics. We somewhat resemble a group of imaginary experts in gas dynamics that track the movement of individual molecules without considering temperature and pressure. We can hardly expect to obtain universal design parameters like in gas dynamics, but this type of characteristics might be obtained for individual classes of problems.

The finite element method raised a new structural mechanics problem of justifying design models: creating and optimizing different types of mesh generation mechanisms.

Considerable attention was drawn to the fact that the problems of the analysis of load-bearing structures focusing on the refined prediction of the peculiarities of the behavior of the system at all stages of its operation including the stages prior to the failure cannot be usually solved by the methods of the linear structural mechanics.
Educational literature [Rudykh et al., 1998] and the majority of researchers [Novozhilov, 1958], [Lukash,1978] consider the following "set of nonlinearities": deviation from Hooke's law (physical nonlinearity), failure to consider the equilibrium conditions in geometrical terms of the non-deformed state (geometric nonlinearity), accounting for the possible changes in the design model during the deformation process (structural nonlinearity). However, this set is not complete. It does not include the consideration of the effects caused by rheological processes in the material (for example, creep) and nonlinear effects of resistance to movements of the dry friction type or of other nature, and it does not take into account nonlinearity related to the accumulation of stress and strain during the changes of the structure as it is created (genetic nonlinearity [Perelmuter and Kabantsev, 2015]). Numerous studies focusing on justification of the design models used here were actively carried out throughout the second half of the $20^{\text {th }}$ century.

The fact that it is impossible to perform a detailed justification of all parameters of a complex design model for an arbitrary structure (especially in the case of a nonlinear analysis) does not mean that we should not perform this type of analysis at all. Apparently, the most powerful strategy is to perform a thorough computer analysis of some typical models, and to compare the results of this calculation with a simplified one. This computational experimentation will let us determine (for a particular class of problems) whether a considerable discrepancy between the calculation and the experiment is a result of unsatisfactory idealization. In fact, we are dealing here with a kind of experimental justification of the design models, with the only difference being that a numerical experiment is used instead of a physical one.

Finally, it should be noted that applied research including the analysis of design models is not always mathematically rigorous, and is often based on credible assumptions [Morris, 1971]. In any case, you should keep in mind that a nonrigorous solution and an incorrect solution are 
fundamentally different things. And most importantly, as is customary in the natural sciences and in engineering, the results are verified by experiment or observation.

\section{REFERENCES}

1. Akyjz F.A., Utku S. An Automatic NodeRelabeling Scheme for Bandwidth Minimization of Stiffness Matrices. // AIAA Journal, 1968, Vol. 6, No. 4, pp. 728-730.

2. Argyris J.H., Kelsey S. The Analysis of Fuselages of Arbitrary Cross-Section and Taper. // Aircraft Engineering, 1954, No. 33, pp. 71-83.

3. Aron H. Das Gleichgewicht und die Bewegung Einer Unendlich Dunnen, Beliebig Gekrummten Elastischen Shale. // J. Reine und Angew. Match., 1874, Vol. 78, pp. 136-173.

4. Basset A.B. On the Exemption and Flexure of Cylindrical and Spherical Thin Elastic Shells. // Phil Trans. Roy. Soc. London, 1891, Ser. A 181, pp. 430-480.

5. Bernoulli J. Essai Theoretique Sur Les Vibrations Des Plaques Elastiques Rectangulaires et Libres. // Nova Acta Academiae Scientiarum Petropolitanae, 1789, Vol. V.

6. Bernshtein S.A. (1936), Ocherk istorii raschota svoda. Issledovaniya po teorii sooruzheniy [Essay in the history of arch design. Studies in the theory of structures], USSR, Moscow-Leningrad, ONTI, 1936.

7. Bolotin V.V. Primenenie Metodov Teorii Veroyatnostei i Teorii Nadyozhnosti v Raschchotakh Sooruzheniy [Use of the Methods of Elasticity Theory in Structures Design], USSR, Moscow, Stroyizdat, 1971.

8. Bubnov I.G. Napryazhenie v Obshivke Sudov ot Davleniya Vody [Stress in Boat Plating from Water Pressure], Russia, Saint-Petersburg, Izdatelstvo Politekhnicheskogo Instituta, 1904

9. Buslenko N.P. Modeling of Complex Systems. Moscow, Nauka, 1968, 327 pages.
10. Calladine C.R. Buckminster Fuller's "tensegrity" structures and Clerk Maxwell's rules for the construction of stiff frames, International Journal of Solids Structures, 1978, Vol.14, pp.161-172.

11. Chebyshev P.L. On Parallelograms. // Trudy Syezda Estestvoispytatelei. Otdel tekhnologii i Prakticheskoi Mekhaniki, Saint-Petersburg, 1870.

12. Chladni E.F.F. Die Akustik, Germany, Leipzig, 1802.

13. Clebsch A. Theorie der Elastizität fester Körper, 1883.

14. Connelly R. The Rigidity of Certain Cabled Networks and the Second Order Rigidity of Arbitrarily Triangulated Convex Surfaces. // Adv. in Math., 1980, Vol. 37, pp. 272-299.

15. Culmann K. Der Bau der Hölzernen Brücken in den Vereinigten Staaten von Nordamerika. // Allgemeine Bauzeitung, 1851, Vol. 16, pp. 69-129.

16. Di Mattio F.I. Statical Indeterminacy and Stability of Structures. // Journal of Structural Division, ASCE, 1963, no. ST3, pp. 63-76.

17. Dickson J. Design of Systems. Moscow, Mir, 1969, 424 pages.

18. Ebner H., Koller Z. Berechnung des Kraftverlaufs. // Versteiften Zylinderschalen, Luftfahrtforschung, 1937, Vol. 14, pp. 607-626.

19. Fenves S.J., Branin F.H. Network Topological Formulation of Structural Analysis. // Journal of Structural Division. ASCE, 1963, Vol. 89, no. ST4, pp. 483-514.

20. Filonenko-Borodich M.M. The Simplest Model of Elastic Foundation Capable of Load Distribution. // Trudy MEMIIT, 1945, Issue 53.

21. Fuller R.B. Tensegrity. // Portfolio and Art News Annual, 1961, No. 4, pp. 112-127.

22. Gantmacher F.R. Teoriya matrits [Theory of Matrices]. USSR, Moscow, Nauka, 1967.

23. Germain S. Recherches sur la Theorie des Suifaces Elastiques. Paris, France, 1821. 
24. Gersevanov N.M. Application of Mathematical Logic to the Analysis of Structures. Moscow, JSTI, 1923, 334 pages.

25. Gersevanov N.M. Primeneniye Matematicheskoi Logiki k Raschotu Konstruktsiy [Application of Mathematical Logic to Structure Analysis]. USSR, Moscow, ONTI, 1923.

26. Goldenblat I.I., Nikolayenko N.A., Polyakov S.V., Ulyanov S.V. Models of Earthquake Engineering. Moscow, Nauka, 1979, 252 pages.

27. Goldenblat I.I., Bazhenov V.L. Physical and Design Models of Structures. // Stroitelnaya Mekhanika i Raschot Sooruzheniy, 1970, No. 2, pp. 23-27.

28. Kartvelishvili N.A., Galaktionov Yu.I. Idealization of Complex Dynamical Systems with Examples from Electrical Engineering, 1976, 272 pages.

29. Kirchhoff G.R. Üeber das Gleichgewicht und die Bewegung Einer Elastischen Scheibe. // Crelle Journal für die Reine und Angewandte Mathematik, 1850, Bd 40, pp. 51-88.

30. Klempert Yu.Z. On Enumeration of Graph Nodes of the System of Linear Algebraic Equations. // Voprosy Optimalnogo Ispolzovaniya EDM v Raschetah Stroitelnich konstrukciy, USSR, Kazan, Isd. Kazanskogo universiteta, 1973.

31. Kosmodemyansky A.A. Theoretical Mechanics and Modern Technology. Moscow, Prosveshenie, 1969, 255 pages.

32. Kuznetsov E.N. Vvedeniye v Teoriyu Visyachikh System [Introduction in the Theory of Suspended Systems], USSR, Moscow, Stroyizdat, 1960.

33. Lamb H. On the Deformation of an Elastic Shell. // Proc. London Math. Soc., 1891, Vol. 21, pp. 119.

34. Leibniz G.W. Demonstrationes Novae de Resistentis Solidorum. // Acte Eruditorum Lipsiae, 1684, pp. 319-325.

35. Love A.E.H. The Small Free Vibrations and Deformation of a Thin Elastic Shell. //
Phil. Trans. Roy. Soc., 1888, Ser. A 179, pp. 491-546.

36. Lukash P.A. Fundamentals of Nonlinear Structural Mechanics. Moscow, Stroyizdat, 1978, 204 pages.

37. Lurie A.I. Statika tonkostennykh uprugikh obolochek [Statics of thin-wall elastic shells], USSR, Moscow, Gostekhizdat, 1947.

38. Manderla H. Die Berechnung der Sekundarspannungen, Welche im Einfachen Fachwerk in Folge starrer Knotenverbindungen Auftreten. // Allgemeine Bauzeitung, 1880, Vol. 45, pp. 27-43.

39. Mariotte E. Traite du Mouvement des Eaux et des Autres Corps Fluides. France, Paris, 1686.

40. Möbius A.F. (1837), Lehrbuch der Statik. Bahd 2, 1837.

41. Mohr O. Beitrag zur Theorie des Fachwerke. Zeitschrift der Architektur und Ingenieurin. Vereines zu Hannover, 1874.

42. Morris W. Management Science: A Bayesian Introduction. Moscow, Mir, 1971, 224 pages.

43. Mstachenko V.N. On Estimation of Adequacy of Design and Real Models of Building Structures. // Stroitelnaya Mekhanika i Raschot Sooruzheniy, 1971, No. 4, pp. 3-7.

44. Myshkis A.D. Elements of the Theory of Mathematical Models. Moscow, Fizmatlit, 1994, 192 pages.

45. Myshkis A.D. Elementy Teorii Matematicheskikh Modeley [Elements of the Theory of Mathematical Models]. Russia, Moscow, Fizmatlit, 1994.

46. Navier C.L.M.H. Resume des Lecons Donnees a L'ecole des Ponts et Chaussees sur L'appliquation de la Mecanique a L'etablissement des Constructions et des Machines. France, Paris, Premiere Partie, 1826.

47. Navier C.L.M.H. Resume des Lecons Donnees a L'Ecole des Ponts et Chaussees sur l'Application de la Mecanique a L'Etablissement des Constructions et des Machines. Vol. 1: Lecons sur la Resistance 
des Materiaux et sur L'etablissement des Constructions en Terre, en Maconnerie et en Charpente, Revues et Corrigees. Vol. 2: Lecons sur le Mouvement et la Resistance des Fluides, la Conduite et la Distribution des Eaux. Vol. 3: Lecons sur L'etablissement des Machines, CarilianGoeury. Paris, France, 1833-1838.

48. Novozhilov V.V. The Theory of Elasticity. Leningrad, Sudpromgiz, 1958, 370 pages.

49. Panovko Ya.G. Mekhanika Deformiruyemogo Tela: Sovremennyie Kontseptsii, Oshibki i Paradoksy [Mechanics of Deformable Body: Current Conceptions, Mistakes and Paradoxes]. USSR, Moscow, Nauka, 1985.

50. Parent A. De la Veritable Mecanique de Resistance des Solides. // Reflections sur la Systeme de M. Bernoulli de Bale Essais et recherches des Mathematiques et des physiques, 1713, Vol. 3, pp. 187-201.

51. Pasternak P.L. Osnovy Novogo Metoda Raschota Fundamentov na Uprugom Osnovanii pri Pomoshchi Dvukh Koeffitsientov Posteli [Principles of a New Method of Foundation Design on Elastic Base With the Help of Two Bed Coefficients], USSR, Moscow - Leningrad, Gosstroyizdat, 1954.

52. Paton E.O. Raschot Skvoznykh Ferm s Zhestkimi Uzlami [Design of Through Trusses With Rigid Nodes], Russia, Moscow, 1901.

53. Perelmuter A.V., Kabantsev O.V. Structural Analysis with a Varying Design Model. Moscow, SCAD Soft, ASV, 2015, 148 pages.

54. Perelmuter A.V., Slivker V.I. Design Models of Structures and a Possibility of Their Analysis. Kiev, Compass Publishing House, 2001, 446 pages.

55. Perelmuter A.V. On Application of Graph Theory to Some Problems of Structural Mechanics. // Stroitelnaya Mekhanika i Raschot Sooruzheniy, 1965, No. 3, pp. 1316.

56. Perelmuter A.V. (1968), "Static and Kinematic Properties of the Systems With Uni- lateral Constraints. // Stroitelnaya Mekhanika i Raschot Sooruzheniy, 1968, No. 2, pp. 18-20.

57. Perelmuter A.V. Ocherki po Istorii Metallicheskikh Konstruktsiy [Essays in the History of Metal Structures], Russia, Moscow, Izdatelstvo SCAD SOFT, Izdatelsky dom ACB, 2015.

58. Perelmuter A.V., Slivker V.I. Peculiarities of Algorithmization of Displacement Method with Allowance for Additional Constraints. // Metod konechnykh elementov i stroitelnaya mekhaniks. Trudy LPI, 1976, No. 49, pp. 28-36.

59. Perelmuter A.V., Slivker V.I. Raschotnyie Modeli Sooruzheniy i Vozmozhnost ikh Analiza [Design Models of Structures and Possibility of Their Analysis]. Ukraine, Kiev, VVP Kompas, 2001.

60. Podolsky D.M. Design of Structural Systems With Ubdeternimed Rigidity Charcteristics. // Nadyozhnost i Dolgovecjnost Mashin i Mekhanizmov, 1984, Issue 6, pp. 78-86.

61. Reissner E. The Effect of Transverse Shear Deformation on the Bending of Elastic Plates. // ASME Journal of Applied Mechanics, 1945, Vol. 12, pp. A68-A77.

62. Schwedler J.W. Theorie der Bruckenbalkensysteme, Zeitschrift fur Bauwesen, 1851, Vol. 1, col. 114-123, 162-173, 265278.

63. Shulkin Yu.B. Kinematic Analysis of Bar Structures. // Raschot Prostranstvennykh Konstruktsiy, 1977, Issue 17, Russia, Moscow. Stroyizdat.

64. Timoshenko S.P. Kurs Teorii Uprugosti, Chast 2. Stoiki i Plity [Course of Elasticity Theory, Part 2. Pillars and Plates]. Russia, Saint-Petersburg, Tipografiya A.E Kollins, 1916.

65. Umansky A.A. On the Theory of Formation of Space Systems. // Raschot Prostranstvennykh Konstruktsiy, 1950, Issue 1, Moscow, Mashstroiizdat, pp. 51-52.

66. Varignon P. Nouvelle Mècanique ou Statique, France, Paris, 1725. 
67. Vlasov V.Z. Contact Problems on the Theory of Shells and Thin-Wall Bars. // Izvestiya AN SSSR. OTN, 1949, No.6 [Republished: Vlasov V.Z. Izbrannyie Trudy, Tom 1, Moscow, Izdatelstvo AN SSSR, 1962].

68. Wieghart K. Über die Balken auf Nachgiebiger Unterlage. // Zeitschrift für Angewandte Mathematik und Mechanik, 1922, 1867, Bd. 2, Heft 3.

69. Winkler E. Die Lerne von der Elastizität und Festigkeit, Czeckia, Prag, 1867.

70. Winkler E. Die Gitterträger und Lager gerader Träger eiserner Brücken. Austria, Vienna, Carl Gerold's Sohn, 1872.

\section{СПИСОК ЛИТЕРАТУРЫ}

1. Akyjz F.A., Utku S. An Automatic NodeRelabeling Scheme for Bandwidth Minimization of Stiffness Matrices. // AIAA Journal, 1968, Vol. 6, No. 4, pp. 728-730.

2. Argyris J.H., Kelsey S. The Analysis of Fuselages of Arbitrary Cross-Section and Taper. // Aircraft Engineering, 1954, No. 33, pp. 71-83.

3. Aron H. Das Gleichgewicht und die Bewegung Einer Unendlich Dunnen, Beliebig Gekrummten Elastischen Shale. // J. Reine und Angew. Match., 1874, Vol. 78, pp. 136-173.

4. Basset A.B. On the Exemption and Flexure of Cylindrical and Spherical Thin Elastic Shells. // Phil Trans. Roy. Soc. London, 1891, Ser. A 181, pp. 430-480.

5. Bernoulli J. Essai Theoretique Sur Les Vibrations Des Plaques Elastiques Rectangulaires et Libres. // Nova Acta Academiae Scientiarum Petropolitanae, 1789, Vol. V.

6. Бернштейн С.А. Очерк истории расчета свода. // Сборник «Исследования по теории сооружений». - М.-Л.: ОНТИ, 1936, c. 228.

7. Bolotin V.V. Primenenie Metodov Teorii Veroyatnostei i Teorii Nadyozhnosti v Raschchotakh Sooruzheniy [Use of the
Methods of Elasticity Theory in Structures Design], USSR, Moscow, Stroyizdat, 1971.

8. Bubnov I.G. Napryazhenie v Obshivke Sudov ot Davleniya Vody [Stress in Boat Plating from Water Pressure], Russia, Saint-Petersburg, Izdatelstvo Politekhnicheskogo Instituta, 1904

9. Buslenko N.P. Modeling of Complex Systems. Moscow, Nauka, 1968, 327 pages.

10. Calladine C.R. Buckminster Fuller's “tensegrity" structures and Clerk Maxwell's rules for the construction of stiff frames, International Journal of Solids Structures, 1978, Vol.14, pp.161-172.

11. Chebyshev P.L. On Parallelograms. // Trudy Syezda Estestvoispytatelei. Otdel tekhnologii i Prakticheskoi Mekhaniki, Saint-Petersburg, 1870.

12. Chladni E.F.F. Die Akustik, Germany, Leipzig, 1802.

13. Clebsch A. Theorie der Elastizität fester Körper, 1883.

14. Connelly R. The Rigidity of Certain Cabled Networks and the Second Order Rigidity of Arbitrarily Triangulated Convex Surfaces. // Adv. in Math., 1980, Vol. 37, pp. 272-299.

15. Culmann K. Der Bau der Hölzernen Brücken in den Vereinigten Staaten von Nordamerika. // Allgemeine Bauzeitung, 1851, Vol. 16, pp. 69-129.

16. Di Mattio F.I. Statical Indeterminacy and Stability of Structures. // Journal of Structural Division, ASCE, 1963, no. ST3, pp. 63-76.

17. Dickson J. Design of Systems. Moscow, Mir, 1969, 424 pages.

18. Ebner H., Koller Z. Berechnung des Kraftverlaufs. // Versteiften Zylinderschalen, Luftfahrtforschung, 1937, Vol. 14, pp. 607-626.

19. Fenves S.J., Branin F.H. Network Topological Formulation of Structural Analysis. // Journal of Structural Division. ASCE, 1963, Vol. 89, no. ST4, pp. 483-514.

20. Filonenko-Borodich M.M. The Simplest Model of Elastic Foundation Capable of 
Load Distribution. // Trudy MEMIIT, 1945, Issue 53.

21. Fuller R.B. Tensegrity. // Portfolio and Art News Annual, 1961, No. 4, pp. 112-127.

22. Gantmacher F.R. Teoriya matrits [Theory of Matrices]. USSR, Moscow, Nauka, 1967.

23. Germain S. Recherches sur la Theorie des Suifaces Elastiques. Paris, France, 1821.

24. Gersevanov N.M. Application of Mathematical Logic to the Analysis of Structures. Moscow, JSTI, 1923, 334 pages.

25. Gersevanov N.M. Primeneniye Matematicheskoi Logiki k Raschotu Konstruktsiy [Application of Mathematical Logic to Structure Analysis]. USSR, Moscow, ONTI, 1923.

26. Goldenblat I.I., Nikolayenko N.A., Polyakov S.V., Ulyanov S.V. Models of Earthquake Engineering. Moscow, Nauka, 1979, 252 pages.

27. Goldenblat I.I., Bazhenov V.L. Physical and Design Models of Structures. // Stroitelnaya Mekhanika i Raschot Sooruzheniy, 1970, No. 2, pp. 23-27.

28. Kartvelishvili N.A., Galaktionov Yu.I. Idealization of Complex Dynamical Systems with Examples from Electrical Engineering, 1976, 272 pages.

29. Kirchhoff G.R. Üeber das Gleichgewicht und die Bewegung Einer Elastischen Scheibe. // Crelle Journal fūr die Reine und Angewandte Mathematik, 1850, Bd 40, pp. 51-88.

30. Klempert Yu.Z. On Enumeration of Graph Nodes of the System of Linear Algebraic Equations. // Voprosy Optimalnogo Ispolzovaniya EDM v Raschetah Stroitelnich konstrukciy, USSR, Kazan, Isd. Kazanskogo universiteta, 1973.

31. Kosmodemyansky A.A. Theoretical Mechanics and Modern Technology. Moscow, Prosveshenie, 1969, 255 pages.

32. Kuznetsov E.N. Vvedeniye v Teoriyu Visyachikh System [Introduction in the Theory of Suspended Systems], USSR, Moscow, Stroyizdat, 1960.
33. Lamb H. On the Deformation of an Elastic Shell. // Proc. London Math. Soc., 1891, Vol. 21, pp. 119.

34. Leibniz G.W. Demonstrationes Novae de Resistentis Solidorum. // Acte Eruditorum Lipsiae, 1684, pp. 319-325.

35. Love A.E.H. The Small Free Vibrations and Deformation of a Thin Elastic Shell. // Phil. Trans. Roy. Soc., 1888, Ser. A 179, pp. 491-546.

36. Lukash P.A. Fundamentals of Nonlinear Structural Mechanics. Moscow, Stroyizdat, 1978, 204 pages.

37. Lurie A.I. Statika tonkostennykh uprugikh obolochek [Statics of thin-wall elastic shells], USSR, Moscow, Gostekhizdat, 1947.

38. Manderla H. Die Berechnung der Sekundarspannungen, Welche im Einfachen Fachwerk in Folge starrer Knotenverbindungen Auftreten. // Allgemeine Bauzeitung, 1880, Vol. 45, pp. 27-43.

39. Mariotte E. Traite du Mouvement des Eaux et des Autres Corps Fluides. France, Paris, 1686.

40. Möbius A.F. (1837), Lehrbuch der Statik. Bahd 2, 1837.

41. Mohr O. Beitrag zur Theorie des Fachwerke. Zeitschrift der Architektur und Ingenieurin. Vereines zu Hannover, 1874.

42. Morris W. Management Science: A Bayesian Introduction. Moscow, Mir, 1971, 224 pages.

43. Mstachenko V.N. On Estimation of Adequacy of Design and Real Models of Building Structures. // Stroitelnaya Mekhanika i Raschot Sooruzheniy, 1971, No. 4, pp. 3-7.

44. Myshkis A.D. Elements of the Theory of Mathematical Models. Moscow, Fizmatlit, 1994, 192 pages.

45. Myshkis A.D. Elementy Teorii Matematicheskikh Modeley [Elements of the Theory of Mathematical Models]. Russia, Moscow, Fizmatlit, 1994.

46. Navier C.L.M.H. Resume des Lecons Donnees a L'ecole des Ponts et Chaussees sur L'appliquation de la Mecanique a L'eta- 
blissement des Constructions et des Machines. France, Paris, Premiere Partie, 1826.

47. Navier C.L.M.H. Resume des Lecons Donnees a L'Ecole des Ponts et Chaussees sur l'Application de la Mecanique a L'Etablissement des Constructions et des Machines. Vol. 1: Lecons sur la Resistance des Materiaux et sur L'etablissement des Constructions en Terre, en Maconnerie et en Charpente, Revues et Corrigees. Vol. 2: Lecons sur le Mouvement et la Resistance des Fluides, la Conduite et la Distribution des Eaux. Vol. 3: Lecons sur L'etablissement des Machines, CarilianGoeury. Paris, France, 1833-1838.

48. Novozhilov V.V. The Theory of Elasticity. Leningrad, Sudpromgiz, 1958, 370 pages.

49. Panovko Ya.G. Mekhanika Deformiruyemogo Tela: Sovremennyie Kontseptsii, Oshibki i Paradoksy [Mechanics of Deformable Body: Current Conceptions, Mistakes and Paradoxes]. USSR, Moscow, Nauka, 1985.

50. Parent A. De la Veritable Mecanique de Resistance des Solides. // Reflections sur la Systeme de M. Bernoulli de Bale Essais et recherches des Mathematiques et des physiques, 1713, Vol. 3, pp. 187-201.

51. Pasternak P.L. Osnovy Novogo Metoda Raschota Fundamentov na Uprugom Osnovanii pri Pomoshchi Dvukh Koeffitsientov Posteli [Principles of a New Method of Foundation Design on Elastic Base With the Help of Two Bed Coefficients], USSR, Moscow - Leningrad, Gosstroyizdat, 1954.

52. Paton E.O. Raschot Skvoznykh Ferm s Zhestkimi Uzlami [Design of Through Trusses With Rigid Nodes], Russia, Moscow, 1901.

53. Perelmuter A.V., Kabantsev O.V. Structural Analysis with a Varying Design Model. Moscow, SCAD Soft, ASV, 2015, 148 pages.

54. Perelmuter A.V., Slivker V.I. Design Models of Structures and a Possibility of
Their Analysis. Kiev, Compass Publishing House, 2001, 446 pages.

55. Perelmuter A.V. On Application of Graph Theory to Some Problems of Structural Mechanics. // Stroitelnaya Mekhanika i Raschot Sooruzheniy, 1965, No. 3, pp. 1316.

56. Perelmuter A.V. (1968), "Static and Kinematic Properties of the Systems With Unilateral Constraints. // Stroitelnaya Mekhanika i Raschot Sooruzheniy, 1968, No. 2, pp. 18-20.

57. Perelmuter A.V. Ocherki po Istorii Metallicheskikh Konstruktsiy [Essays in the History of Metal Structures], Russia, Moscow, Izdatelstvo SCAD SOFT, Izdatelsky dom ACB, 2015.

58. Perelmuter A.V., Slivker V.I. Peculiarities of Algorithmization of Displacement Method with Allowance for Additional Constraints. // Metod konechnykh elementov i stroitelnaya mekhaniks. Trudy LPI, 1976, No. 49, pp. 28-36.

59. Perelmuter A.V., Slivker V.I. Raschotnyie Modeli Sooruzheniy i Vozmozhnost ikh Analiza [Design Models of Structures and Possibility of Their Analysis]. Ukraine, Kiev, VVP Kompas, 2001.

60. Podolsky D.M. Design of Structural Systems With Ubdeternimed Rigidity Charcteristics. // Nadyozhnost i Dolgovecjnost Mashin i Mekhanizmov, 1984, Issue 6, pp. 78-86.

61. Reissner E. The Effect of Transverse Shear Deformation on the Bending of Elastic Plates. // ASME Journal of Applied Mechanics, 1945, Vol. 12, pp. A68-A77.

62. Schwedler J.W. Theorie der Bruckenbalkensysteme, Zeitschrift fur Bauwesen, 1851, Vol. 1, col. 114-123, 162-173, 265278.

63. Shulkin Yu.B. Kinematic Analysis of Bar Structures. // Raschot Prostranstvennykh Konstruktsiy, 1977, Issue 17, Russia, Moscow. Stroyizdat.

64. Timoshenko S.P. Kurs Teorii Uprugosti, Chast 2. Stoiki i Plity [Course of Elasticity 
Theory, Part 2. Pillars and Plates]. Russia, Saint-Petersburg, Tipografiya A.E Kollins, 1916.

65. Umansky A.A. On the Theory of Formation of Space Systems. // Raschot Prostranstvennykh Konstruktsiy, 1950, Issue 1, Moscow, Mashstroiizdat, pp. 51-52.

66. Varignon P. Nouvelle Mècanique ou Statique, France, Paris, 1725.

67. Vlasov V.Z. Contact Problems on the Theory of Shells and Thin-Wall Bars. // Izvestiya AN SSSR. OTN, 1949, No.6 [Republished: Vlasov V.Z. Izbrannyie Trudy, Tom 1, Moscow, Izdatelstvo AN SSSR, 1962].

68. Wieghart K. Über die Balken auf Nachgiebiger Unterlage. // Zeitschrift für Angewandte Mathematik und Mechanik, 1922, 1867, Bd. 2, Heft 3.

69. Winkler E. Die Lerne von der Elastizität und Festigkeit, Czeckia, Prag, 1867.

70. Winkler E. Die Gitterträger und Lager gerader Träger eiserner Brücken. Austria, Vienna, Carl Gerold's Sohn, 1872.

Anatolii V. Perelmuter, Foreign member of the Russian Academy of Architecture and Construction Sciences, Professor, Doctor of Science, SCAD Soft, Ltd;

3a, Osvity street, office 2, Kiev, 03037, Ukraine;

E-mail:avp@scadsoft.com.

Перельмутер Анатолий Викторович, иностранный член РАACH, профессор, доктор технических наук; НПО СКАД Софт; 03037, Украина, г. Киев, ул. Освиты, дом 3a, офис 2; e-mail: avp@scadsoft.com. 